\title{
The Social Use of Batonu Personal Names
}

\author{
Cecilia A. Ajiboye, Omobola A. Aladesanmi \& Oluwatoyin M. Olaiya \\ cecylqueen2003@yahoo.com; bolaaladesanmi@gmail.com; toyinmolaiya@gmail.com \\ Kwara State College of Education, Oro; Ekiti State University, Ado-Ekiti; Ekiti State University, \\ Ado-Ekiti, NIGERIA.
}

\begin{abstract}
Previous researchers on the use of Batonu personal names argue that there are different categories of Batonu names and using thirty (30) respondents, the researchers submit that the use of Muslim names has replaced the use of Batonu native names in all domains. However, the present study, using three hundred (300) respondents, visited the study area and identifies names that are used as personal names among the Batonu people. It also examines the social use of the names in formal and informal domains. The research adopted the theory of Domains of language use by Ferguson (1966). Questionnaires and interviews were used to collect data on the various uses of personal names in intra and inter group interactions. There were three findings. Some showed names that were drawn from Islam and Christianity. Some names were also drawn from Batonu native names. Two domains of name usage have been identified. The informal domains consisted of home/community, peer-group and play ground. The formal ones comprised school, places of worship, certificates, wedding cards, almanacs and work places. It is evident that the Batonu native names are still frequently used with foreign or Christian and Muslim names in formal and in informal domains although with different degrees of use. This present study has shown that although a foreign culture may have an overwhelming influence over an indigenous culture, it does not mean that the indigenous culture will not thrive especially if the indigenous culture has traditional activities that can help sustain it.
\end{abstract}

Article

information Received:

3 July 2019

Revised:

14 August 2019

Accepted:

1 September 2019

Keywords: Domains, Islam; Christianity; Culture; Names

DOI: 10.24071/joll.v20i2.2853

Available at https://e-journal.usd.ac.id/index.php/JOLL/index

This work is licensed under a Creative Commons Attribution-ShareAlike 4.0 International License.

\section{Introduction}

The history of Batonu people of Baruten local communities is the history of semiautonomous kingdoms which originated from Borgu Empire (see Welmers, 1952; Sanusi, 1983). The original Borgu Empire was made up of the present Borgu in Nigeria and the present Borgu in the Republic of Benin. Originally, Borgu was also an empire of three brothers namely Woru of Bussa (eldest), Sabi of Nikki in Benin Republic and Bio of Illo (youngest) in Kebbi State of Nigeria. The three were sons of Kisra who led them across the Sahara from Arabia through Chad to the present day Borgu (Stawart, 1985). It will be recalled that Borgu was divided amongst the three brothers. Woru was put in charge of the east and central, and he found Bussa as his capital. Sabi took charge of the southern and 
western areas and made Illo as his own capital. As a result, Borgu-Nigeria became divided into three divisions namely north, central and south. The north includes Illo, Kaoje and Kwanji. The central area is placed under Bussa while the south includes the kingdoms of Kenu, Banara, Tabira, Ilesha-Baruba (in Ilorin), Okuta and Yashikira to mention but a few. Each of the above districts claimed hegemony over others. Kosubosu (an hamlet) is chosen as its headquarters.

Geographically, the territory enclosed within $9^{0}$ and $12^{\circ}$ parallels of Latitude and $1^{\text {st }}$ and $4^{\text {th }}$ meridians of east Longitude comprising an area of about ten thousand (10, 000) square miles, is the South-Western Borgu which is referred to as 'Batonu' land in this research. This land lies within high plains with few hills around (Sabi, 2017). The plains are broken by valleys while wet and dry seasons are distinct. During the dry seasons, most festivals and ceremonies are celebrated in Batonu land. Batonu land also marks the Western end of the Middle Belt region of Nigeria in Kwara State and it is bordered on the west by an international boundary of the Republic of Benin; on the east, it shares boundary with Kaima in Kaima local government area of Kwara State; on the northern axis, it shares boundary with Niger State while on the south it shares with Oyó State in Nigeria. In the Republic of Benin; Batonu is spoken in places like Parakou, Nikki, Kandi and Nantitingou. The major Batonuspeaking areas in Nigeria include Kosubosu (its headquarters), Okuta, Ilesha-Baruba, Yashikira, Chikanda and Gwanara in Baruten local government of Kwara State. Some of her neighbouring languages in Nigeria include Bokobaru, Bisayan, Nupe and Yorùbá.

Furthermore, the Batonu land emerged as a result of the colonial occupation of the region, which led to its demarcation in 1899 between the French and the British people as a result of the scramble for territories between the major European powers (Sabi, 2017). Before the demarcation, both Nigerian and Dahomean Borgu was a single political entity that cherished a common tradition and ancestry. After so many complex series of negotiations, there came the Anglo-French convention in 1898. In that convention, Borgu was divided between the British and the French people; Fredrick Lugard (on British side) and Decoeur (on the French side) secured a treaty on Nikki. Nikki and its provinces were given to the French while Okuta, Yashikira, Ilesha-Baruba and Gwanara districts were given to the British. The area enslaved by the British is referred to as the Nigeria Borgu which is made up of the present Baruten and Kaiama local government areas of Kwara State and Borgu and Agwara local government areas of Niger State. The French Borgu is the area enslaved by the French under the control of Dahomey which is now the Benin Republic. The people of Batonu land are a homogenous society which has linguistic variations and remain a single political and geographical entity. Three broad descriptive terms could be used to identify the groups of people who dwell or inhabit Batonu land. These include the Aborigines, the Wassangaris and the Commoners who are subdivided into Gando and Mareyo.

Still on the history of the Batonu people, the Batonu land is predominantly a wooden region and the major occupation is farming. The Batonu people inhabited the savannah zone and are blessed with natural resources. Rainfall is ample and crop farming is common. They also supplement farming with hunting. Markets of the people of Batonu include Okuta market, Gure market, Ilesha-Baruba cattle market (in Kwara State), Chikanda market, Shinawa market, among others. People come from different parts of the country to purchase yams, yam flour (known as 'èlùbọ́' in Yorùbá), cassava, maize, guinea corn and groundnuts which are the major agricultural products of the people of Batonu for commercial purposes. Up till now, animals like sheep, goats, cattles and poultry serve as foods and for income while horses are kept for transportation and military purposes.

The Batonu people are also said to be good archers and good night-guards. Many of them have worked in neighbouring areas such as Yorùbá land. There is the belief that they have herbal prowess and this is the reason why it is claimed that one man alone can watch over a town or a village and be seen at various parts of such a town. But most of the Batonu natives who work as guards are said to have come 
from Dahomean Borgu that is now in the Republic of Benin. These people are referred to as great warriors and herbal experts because they are said to have fought many wars with their neighbouring villages (Sabi, 2017).

Culturally, festivals of Batonu people also interest people and the festivals make people from different parts of the world to visit the area. Such festivals include the 'Gaani' festival, the yam festival, the marriage ceremony, the naming ceremony, Eid-el-Malud, Eid-el-Kabir and Eid-el-Fitri festivals. Of all the festivals mentioned above, the 'Gaani' festival seems to have gained much attention because it reminds the people of their common ancestry. The festival is a state festival and it is a well known, age-long festival that has been associated with the people. The festival is used to appease the Batonu land. It is, therefore, very paramount to the people and it helps the Batonu people economically, politically and socially. The 'Gaani' festival is loved by all. The festival is celebrated and held with pride by the Batonu people. It has survived western and colonial influences, because its observation in the past years and in recent times is alike except for few modifications. The Gaani festival began as a means of celebrating the new yam before the advent of Islam.

Linguistically, Batonu is a language of the Gur, a sub-group of the Niger-Congo family of the Niger-Kordofanian phylum which is spoken in Nigeria (see Sanusi 1983, 2001). It is the language of the people called 'Batombu' or 'Batonu' (a name given to the native speakers). Both the language and its speakers are popularly referred to by non-native speakers such as Yorùbá and Hausa as "Baruba" or "Bariba" or Burgawa". Scholars like Welmers (1952) and Sanusi (1983) claim that they have voltaic and Sudanese roots and that their society is patrilineal. The Batonu language is spoken as a first language in two adjacent countries in West Africa: Nigeria and the Republic of Benin (Welmers, 1952, 1973; Sanusi, 1983; British Broadcasting Corporation, 1993). In all, native speakers of Batonu language are a little above 400,000 in both Nigeria and the Republic of Benin (Sabi, 2017). While the Batonu population in Nigeria is said to be 60,000 , that of the Republic of
Benin is 342,000 (see Vanderaa, 1991; Sabi, 2017).

Studies that have been conducted in the areas of naming and names are common in books and journal articles. Some of such researchers whose findings are in books include Searle (1958), Strawson (1959), Sowande and Ajanaku (1969), Adeoye (1972), Babalola and Alaba (2003) and Ogunwale (2003). Some others whose works have appeared in journals are Evans-Pritchard (1948), Geertz (1973), Goodenough (1965), Ekundayo (1977), Akinnaso (1980), Oyetade (1995) and Ikotun $(2010,2013,2014)$. One deduction from the previous studies shows that while Evans-Pritchard (1948) and Geertz (1973) claim that names do not have semantic contents and that they are mere labels, other researchers argue that names have sociocultural information because they are reflections of events, values and beliefs.

Furthermore, according to the previous researchers, names that are reflections of events, values and beliefs include names that are brought from heaven, names that show people's belief in deities, chieftaincy names, war names, nicknames, names that are given to those that die and are perceived to have been born again, names that exhibit family professions and the ones that show people's belief in reincarnation. Ikotun and Aladesanmi (2012) and Ikotun (2013) have also shown that the introduction and acceptance of Christianity in some areas of Nigeria have made some Nigerians to re-work their names. For example, while Ikotun (2013) argues that some names that are products of acculturation are being adopted by some Yorùbá people instead of the tradition-based Yorùbá personal names Ikotun and Aladesanmi (2012) report that some Yorùbá Christians have either deleted the noun phrases (NPs) of their surnames because the NPs show reference to some Yorùbá deities or replaced their surnames with biblical or Christian names. Another research endeavour that has to do with the focus of this present research is Fakuade et al (2018). Fakuade et al (2018) identify the different Batonu names and submit that the use of Muslim names has replaced the Batonu names in both formal and informal domains. In this paper, we are 
interested in the use of Batonu personal names and three questions that have not been addressed by any of the previous researchers are (1) Have the Batonu native names been completely replaced by Muslim names? (2) Are there no occasions where Batonu native names are used? (3) Does it mean that Christian names are not used among the Batonu people? These questions will be addressed in this research work.

One area of previous research works that is of interest to our present study of Batonu personal names is culture. Culture is defined by Taylor (1892, p.1) as:

that complex whole which includes knowledge, belief, art, law, morals, customs and all other capabilities and habits acquired by man as a member of society.

According to Andarh (1982, p.5) also,

Culture embraces all the material and nonmaterial expression of a people as well as the process with which the expressions are communicated. It has to do with all the social, ethical, intellectual,

scientific, artistic and technological expressions and processes of a people usually ethnically and or nationally or supranationally related and usually living in a geographically contiguous area; what they pass on to their successors and how these are passed on.

However, the interaction between naming and culture shows that previous researches on naming practices or personal names are in two categories. For example, Evans-Pritchard (1948) and Geertz (1973), who belong to the first group or category, claim that in some cultures, names are mere labels that do not have linguistic structure and semantic contents. The second category which comprises Searle (1958), Martins (1959), Strawson (1959) Goodenough (1965), Ekundayọ (1977), Akinnaso (1980), Adeniyi (2004) and Ikotun $(2010,2013,2014)$ submits that names reflect events, values and beliefs which have psychological and socio-cultural information.
Furthermore, according to Akinnaso (1980), all human beings or group use personal names as a system of individual identification and that the linguistic and cultural implications vary from one culture to another and that the Yorùbá naming system is based on home contexts such as beliefs, lineage, individual social values and expectations. For example, Yorùbá names that are reflections of beliefs, lineage, individual social values and expectations have been divided into different categories and some examples are presented below (see also Śówándé and Àjànàkú 1969; Adéoyè, 1972; Babalọlá and Âlàbá 2003; Ìkọ̀tún, 2013; Ògúnwálé, 2016). The first category claims that there are some names that are called 'àmútòrunwá' (names that are brought from heaven) and some examples are: İgè (a child who presents the leg first rather than the head at birth) and òké (a child born with an unbroken membrane). The second category is concerned with the names of Yorùbá deities or gods and they include: Ògún (The god of iron), Èsù (The law enforcer) and Ifá (The god of wisdom) to mention but a few. The third category comprises names that are called 'ìnagije' (nicknames).

In addition, names that belong to the fourth category include 'orúkọ àbíkú' (names that are given to those that die and are perceived to have been born again or have staged a comeback). An example of such names is Kúkòyí (Death rejected this one). Names that show individual social values and expectations like Odúnolá (Festival of happiness) belong to the fifth category. The sixth category contains names that deal with 'issẹ ìdílé' (family professions) such as Odẹ́wálé (A hunter came home). The seventh category consists of names that show the Yorùbá people's belief in 'asèỳinwáyé' (reincarnation) like İyábò (The mother came back) while names such as Àbíké (Praise name) and Àkànjí (Praise name) that are drawn from 'oríki' (eulogy) belong to the eighth category. We agree with the previous researchers that claim that there is an interwoven relationship between naming and culture. We also want to submit that it is not only African names that are reflections of events, values and beliefs, names of people from several other ethnic groups of the world especially the Jews and the 
Arabs also reflect values and beliefs. Some examples of such names among the Jews are as follows (see Insight on the Scriptures, 1988):

$\begin{array}{ll}\text { Ezra } & \text { (Help) } \\ \text { Joshua/Jehoshua } & \begin{array}{l}\text { (Jehovah is } \\ \text { Salvation) }\end{array} \\ \text { Nehemiah } & \text { (Jehovah comforts) } \\ \text { Peleg } & \text { (Division) }\end{array}$

Similarly, some examples below are also presented among the Arabs (see The Holy Quran):

$\begin{array}{ll}\text { Abdul Raheem } & \begin{array}{l}\text { (The servant of God } \\ \text { that is merciful) }\end{array} \\ \text { Tahmeed } & \text { (Thanking God) } \\ \text { Miftau } & \text { (Key) } \\ \text { Hajara } & \text { (Stone) } \\ \text { Abdul Hakeem } & \text { (The servant of God } \\ & \text { that has wisdom). }\end{array}$

In this study of Batonu personal names also we will determine the Batonu personal names that reflect events, values and beliefs.

Another area of interest to our present study of Batonu personal names is acculturation. Turnbull (2010) defines acculturation as "the adoption of the behaviour patterns of the surrounding culture". The surrounding culture, in this case especially in Nigeria, may mean Christian culture, Islamic culture and any other Nigerian culture like the case of Yorùbá culture in Ebira land. Research studies that show some African names as products of acculturation include Ìkọ̀tún and Aládésanmí (2012), İkòtún (2013) and Fakuade et al. (2018). Names that are products of acculturation which Africans now adopt either as first names or surnames can be classified into four categories. For example, Ìkọ̀tún and Aládésanmí (2012) report that while some Noun Phrases (NPs henceforth) of some Yorùbá personal names which show the names of some Yorùbá gods such as Ifá, Ògún, Oya and Sàngó have been replaced with the Bible 'Olúwa' (Lord), some of such NPs have been deleted completely. Examples of such names are in categories A and B below.

\section{Category A}

Ògúnyẹmí $\longrightarrow$ Olúwáyẹmí

(The god of iron fits me) (The Lord fits me)

Ògúnbùnmi $\longrightarrow$ Olúwábùnmi

(The god of iron has given me) (The Lord has given me)

Șàngób́íyìi $\longrightarrow$ Oluwabíyìi

(The god of thunder has given birth to this) (The Lord has given birth to this)

\section{Category B}

Fájẹ́milóhùn $\longrightarrow$ Jẹ́milóhùn

(The god of wisdom made me to have a voice) (Let me have a voice)

Fágbénró $\longrightarrow$ Gbénró

(The god of wisdom upheld me) (Uphold me)

Ògúnbíyìi $\longrightarrow$ Bíyî́

(The god of iron has given birth to this) (Gave birth to this) 
Ìkòtún (2013) and Fakuade et al. (2018) have also discussed the adoption and use of foreign names by Africans. While İkọ̀tún (2013 discusses the adoption and use of Biblical and European names by some Yorùbá Christians, Fakuade et al. (2018) discuss the adoption and use of Islamic/Muslim names by the Batonu people. We want to add also that, at present, using personal names as a system of individual identification especially with reference to ethnicity, it is difficult to identify some Yorùbá Christians as Yorùbá and some Yorùbá Muslims also as Yorùbá. This is because while some Yorùbá Christians adopt Biblical or European names as first names and surnames, some Yorùbá Muslims adopt Islamic or Muslim names as first names and surnames. So, there are instances where some Yorùbá Christians are now addressed as "Daniel Enoch", "John David", "Johnson Macaulay" and "Benson Gold" while some Yorùbá Muslims are addressed as "Abdulganiyu Quadri", "Jimoh Usman", and "Abdulrazak Allison" to mention a few. However, one question that will be addressed in this present research is: Are there some Batonu personal names that have been modified or reworked or rejected?

The research work that has been carried out on the use of surnames among the Yorùbá sub-ethnic groups is also of interest to our present study. A surname is a name that is common to a family and is often used with the English titles such as Mr, Ms, Mrs or Miss (see also Turnbull, 2010: 1503). İkòtún (2014) argues that surnames form one of the parameters that can be used to distinguish the Yorùbá sub-ethnic group members from one another and such surnames which indicate Yorùbá sub-ethnic group affinities are tradition-based personal names which depict traditional religions or deities that were peculiar to each Yorùbá sub-ethnic group before the advent of Christianity. According to him, the tradition - based surnames now serve as reminders of the religious activities of the Yorùbá people before the advent of Christianity.

Similarly, three other inferences can be drawn from the use of tradition-based surnames. First, the use of tradition-based surnames can also help to distinguish a member of one ethnic group from another. For example, tradition-based surnames such as Dúrójayé (Stay to enjoy life), Ògúnyemí (The god of Iron fits me) and Fásèyí (The god of wisdom made this) will indicate the users of the surnames as Yorùbá while users of surnames like Uzor (A road for success), Orji (Nothing will happen to me because I am a god of myself) and Mbadiwe (The villagers are angry) are from the Igbo ethnic group. Second, there are some names whether traditionbased or not which can help to distinguish members of a family from another members of another family in a community. Such names may include 'Fájémisin' (Ifá has allowed me to worship), 'Odewale' (The hunter has come home) and 'Ayodele' (Joy has reached home) to mention a few. Third, the linguistic and cultural information contained or present in tradition-based names show how the users of such names see and interpret the world around them. Again, in this work, we will find out if the Batonu personal names still include tradition-based names.

The study of domains with reference to language use and language maintenance is also relevant to our present study of Batonu personal name usage. Studies that have been conducted with reference to domains include Ferguson (1966), Kaye (1972), Gambhir (1983), İkọ̀tún and Soyoyè (2002). According to Ferguson (1966), there are three dialects of the Arabic language and that while one of the dialects is the standard variety that is used in inter-group interactions, the other two which are Christian and Muslim dialects are the low varieties and are used in intra-group interactions. He also argues that the varieties, that are functionally kept apart, are genetically related and they have mutual intelligibility. However, reactions from Kaye (1972), Gambhir (1983), Ìkọ̀tún and Soyoyè (2002) show that Ferguson's (1966) distinction between the High and Low varieties is debatable. They argue that while some elite may use the High variety in both intra and inter-group interactions, those who are not well read and who are likely to be in the majority will certainly use the Low varieties in formal and informal domains or intra and inter-group interactions.

We agree with Kaye (1972), Gambhir (1983), İkọ̀tún and Soyoyè (2002) because the 
highly educated ones may decide to use the High variety in both formal and informal domains while the illiterates will use the Low varieties in both formal and informal domains as well. We are also of the opinion that, considering the socio-linguistic studies carried out by Gòkè-Paríolá (1983), Ekúndayọ̀ (1977), Oyetade (1990) and Ikotun (2006) on codemixing and linguistic borrowing, it is not unlikely that speakers of the High and Low varieties will code-mix words from the varieties that are available in their linguistic repertoire both in inter and intra-group interactions. In other words, we insist that the educated and the uneducated will use both the tradition-based and foreign names that are known to them as forms of address in inter and intra-group interactions. However, in our present study of Batonu personal names, we will consider the concept of language use by Ferguson (1966). This will help us to determine the domains of personal name usage among the Batonu people of Nigeria.

Language shift or name shift is also of interest to our present study of Batonu personal names. According to Fishman (1991), language shift is a "process whereby intergenerational continuity of the heritage languages is proceeding negatively with fewer speakers, readers, writers and even understanders." Evidence from existing studies on personal names shows that Fishman's (1991) definition of l anguage shift can also include name shift. For example, a research carried out by Fakuade et al. (2018) on Batonu personal names shows that there is a shift in Batonu naming practices. They argue that the shift is caused by the introduction and acceptance of the Islamic religion in the Batonu land. We agree with Fakuade et al. (2018) that the phenomenon of foreign cultural systems namely Islam and Christianity has strongly affected the use of tradition-based names especially as first names among several ethnic groups of the world particularly where Islam and Christianity are dominant.

As far as first names are also concerned, we can say that, using Fishman's (1991) definition, name shift is not only a process where intergenerational continuity of the tradition- based names is proceeding negatively with fewer users but also with high detestation by several people. But, there is a difference between Christian and Muslim influence on naming practices among some ethnic groups in Nigeria. Among the Yorùbá Christians, first names are in two categories. The first category comprises names that are drawn from the Bible and they include John, Paul, Luke, Abraham, Mary, Dorcas and Joseph to mention a few. The second category consists of names or derivations that are sentences which may have the Biblical Olúwa (Lord) as their NPs or may appear as verbal phrases (VPs) and the names will reflect the parental beliefs, aspirations and desires. Examples of new derivations which some Yorùbá parents now adopt as names for their children are: Tijésùnimí or Tijésù or Nimí (I am for Jesus) and Tolúwani or Tolú (He/She is for the Lord). The case with the Muslims is different because Arabic names are still preferred and are commonly used. For example, only names like Ibrahim, Hajarat, Sekinat, Bashir and Mohammed to mention a few are still adopted by the Muslims.

However, in view of our knowledge of Yorùbá and Igbo cultural systems of intergenerational continuity of Olớjọ́ festival at IléIfè̀ or Oșun Òșogbo festival in Òsogbo or New Yam festival in Igbo land and the naming practices, it is not unlikely that there are some Batonu people who, though their parents are Muslims and they were given Muslim names at birth, decide to endorse the Batonu cultural norms and the naming practices now that they are of age. We are of this opinion because there are instances where some Yorùbá people whose ages are below forty years and who are addressed Ifáșèyí (The god of wisdom made this one), Ifáyermí (The god of wisdom fits me) and Ifásanmí (The god of wisdom is beneficial to me) even when their parents answer either Christian or Muslim names. In our present study of the Batonu naming practices, we want to expand the scope of the existing studies and find out if Christianity also has a negative effect on the Batonu naming practices. In our opinion too, we are not convinced that thirty (30) respondents are sufficiently representative of the sixty thousand $(60,000)$ Batonu speakers. Therefore, we will use three hundred (300) respondents so as to confirm whether there is a shift from the use of Batonu names to the use 
of only Muslim names as revealed by Fakuade, et al. (2018).

\section{Methodology}

This study is descriptive and it adopted the theory of domains of language use by Ferguson (1966). The data for the research were collected from three sources: attendance registers in primary and secondary schools where bio-data of students were clearly shown. This was to ascertain personal names that were used in schools. Questionnaires were used to collect data on the various personal names in the home and intra-peer group interactions. Data from this source helped to ensure natural language use with reference to personal names that were used in intra-group interactions. Similarly, data from the school domain as well as data from home and intra-peer group interactions helped us to confirm if there were differences between personal names that were used in formal and in informal domains. Interviews were also conducted among some elderly Batonu people in Kwara State to determine the cultural factors that influence the use of personal names that were given to children when they were born. Three hundred people were randomly selected for the interview.

\section{Results and Discussion}

This section contains the presentation of findings and the analysis. The findings show the use of Batonu personal names which comprise Batonu native and Christian/Muslim names in both formal and in informal domains. The findings and the analysis are divided into two sub-sections. The information in Tables 1 , 2, 3 and 4 below shows the different categories of names that are adopted as personal names among the Batonu people.

Table 1. Religious names

\begin{tabular}{|c|l|l|l|l|}
\hline \multicolumn{3}{|c|}{ Islamic Names } & \multicolumn{2}{c|}{ Christian Names } \\
\hline S/N & Male & Female & Male & Female \\
\hline 1. & Zakari & Fatimoh & Joshua & Dorcas \\
\hline 2 & Mohammed & Rukayat & Daniel & Janet \\
\hline 3 & Yahaya & Halimat & Isaac & Hannah \\
\hline 4 & Yusfu & Jelilat & Emmanuel & Ruth \\
\hline 5 & Jimoh & Hawawu & John & Elizabeth \\
\hline 6 & Abdullahi & Nafisat & David & Mary \\
\hline 7 & Abdukabir & Sekinat & Gideon & Martha \\
\hline 8 & Abdulkareem & Ayishatu & Ezekiel & Comfort \\
\hline 9 & Ibrahim & Fausat & Peter & Deborah \\
\hline 10 & Bashiru & Jemilat & Paul & Esther \\
\hline
\end{tabular}

In Table 1 above, there are two categories of names. The first category consists of Islamic names while the second category comprises Christian names. 
Table 2. The use of Batonu personal names in Formal Domains

\begin{tabular}{|c|c|c|c|c|c|}
\hline DOMAINS & RESPONDENTS & $\begin{array}{l}\text { BATONU } \\
\text { NAMES }\end{array}$ & $\begin{array}{c}\text { MUSLIM/ } \\
\text { CHRISTIAN } \\
\text { NAMES }\end{array}$ & $\begin{array}{l}\text { TOTAL IN } \\
\text { FIGURES }\end{array}$ & $\begin{array}{c}\text { PERCENTAGE } \\
(\%)\end{array}$ \\
\hline \multicolumn{6}{|l|}{ School: } \\
\hline Primary & 40 & $24(60 \%)$ & $16(40 \%)$ & 40 & $100 \%$ \\
\hline Secondary & 35 & $20(57.14 \%)$ & $15(42.85)$ & 35 & $99.99 \%$ \\
\hline Tertiary & 25 & $15(60 \%)$ & $10(40 \%)$ & 25 & $100 \%$ \\
\hline Church: & 100 & $73(73 \%)$ & $27(23 \%)$ & 100 & $100 \%$ \\
\hline Mosque & 100 & $68(68 \%)$ & $32(32 \%)$ & 100 & $100 \%$ \\
\hline \multicolumn{6}{|l|}{ Certificates: } \\
\hline $\begin{array}{l}\text { Birth/Death } \\
\text { registration: }\end{array}$ & 100 & $62(62 \%)$ & $38(38 \%)$ & 100 & $100 \%$ \\
\hline Marriage. & 100 & $59(59 \%)$ & $41(41 \%)$ & 100 & $100 \%$ \\
\hline Wedding cards & 100 & 57 (57\%) & $43(43 \%)$ & 100 & $100 \%$ \\
\hline $\begin{array}{l}\text { Almanacs of } \\
\text { Batonu Couples. }\end{array}$ & 100 & $60(60 \%)$ & $40(40 \%)$ & 100 & $100 \%$ \\
\hline Workplace & 100 & $66(66 \%)$ & $34(34 \%)$ & 100 & $100 \%$ \\
\hline
\end{tabular}

From Table 2 above, it can be observed that about 24 of the respondents, representing $60 \%$ of the population used Batonu native names in primary schools while in secondary schools, 20 respondents, representing $57.14 \%$ used Batonu native names. In the tertiary institutions, 15 of the respondents, representing $60 \%$ used Batonu native names. In the religious circle (church/mosque), the result showed that $73 \%$ (73) of the respondents who are Christians and 68\% (68) of the respondents who are Muslims used foreign names (Christian/Muslim names), while $27 \%$ (27) and $32 \%$ (32) of the respondents used Batonu native names.

At work place, $66 \%$ (66) of the respondents used Batonu native names while $34 \%$ (34) used foreign names. On certificates of birth and death, the result revealed that $68 \%$ (68) of the respondents used Batonu native names as against 32\% (32) who used religious/foreign names. 59\% (59) of the respondents used Batonu native names under marriage registration while $41 \%$ (41) used religious/foreign names. $60 \%$ (60) of the respondents used Batonu native names on Almanacs while 40\% (40) used foreign names. Here, Batonu native names and foreign names were used but there is a more preponderance in the use of Batonu native names over Christian/Muslim names. 
Table 3: The use of Batonu personal names in Informal Domains.

\begin{tabular}{|l|c|c|c|c|c|}
\hline DOMAINS & RESPONDENTS & $\begin{array}{c}\text { BATONU } \\
\text { NAMES }\end{array}$ & $\begin{array}{c}\text { MUSLIM/ } \\
\text { CHRISTIAN } \\
\text { NAMES }\end{array}$ & TOTAL & $\begin{array}{c}\text { PERCENTAGE } \\
\text { (\%) }\end{array}$ \\
\hline Home/Community & 100 & $\begin{array}{c}88 \\
(88 \%)\end{array}$ & $\begin{array}{c}22 \\
(22 \%)\end{array}$ & 100 & $100 \%$ \\
\hline Naming & 100 & $\begin{array}{c}72 \\
(72 \%)\end{array}$ & $\begin{array}{c}28 \\
(28 \%)\end{array}$ & 100 & $100 \%$ \\
\hline Peer-groups & 100 & $\begin{array}{c}74 \\
(74 \%)\end{array}$ & $\begin{array}{c}26 \\
(26 \%)\end{array}$ & 100 & $100 \%$ \\
\hline Playground & 100 & $\begin{array}{c}75 \\
(75 \%)\end{array}$ & $25 \%)$ & 100 & $100 \%$ \\
\hline
\end{tabular}

Table 3 shows the use of Batonu native names in informal domains. Such domains include homes / communities, peer group/ playground. The Table shows that $88 \%$ (88) of the respondents used Batonu native names at homes/ communities as against $22 \%$ (22) of the respondents that used Christian/Muslim names. 74\% (74) of the respondents used Batonu native names among peers in their various groups while $26 \%$ (26) used religious names. On playground, $75 \%$ (75) of the respondents used Batonu native names while $25 \%$ (25) of the respondents that comprised Muslims and Christians used non-Batonu native names. Here, the use of Batonu native names is predominant over religious names in informal domains because Batonu native names are culture-based. 
Table 4. Use of Batonu and Muslim/Christian Names

\begin{tabular}{|c|c|c|c|c|c|c|c|c|}
\hline \multirow{2}{*}{ 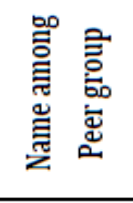 } & $\frac{u}{\Sigma}$ & $\sim \stackrel{\circ}{\mathrm{a}}$ & ๙ & 워 & 웡 & 品 & 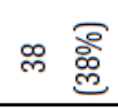 & ০ \\
\hline & ఐ & + & $\therefore \frac{2}{2}$ & ঊ 高 & ホす & 총 & זั స్త్ర & 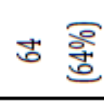 \\
\hline \multirow{2}{*}{ 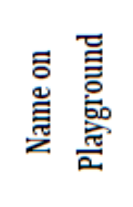 } & $\stackrel{v}{\Sigma}$ & น & ॰ & ন స్త్ర & 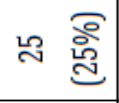 & ㅎㅇㅇ & 品 & ஓ 今్ \\
\hline & 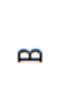 & 올 & 잉 & 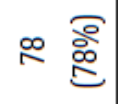 & 용 & ㅎ & 총 & $\therefore \stackrel{\circ}{\circ}$ \\
\hline \multirow{3}{*}{ 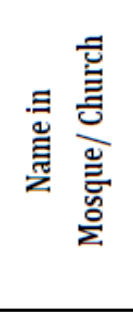 } & $\cup$ & $9 \stackrel{\circ}{9}$ & $=\stackrel{Ð}{\stackrel{\Xi}{\Xi}}$ & 응 일 & 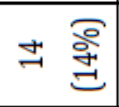 & 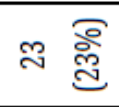 & ণ ఏ్రి & $\therefore \stackrel{\circ}{\Xi}$ \\
\hline & $\Sigma$ & मे 总 & 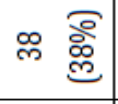 & 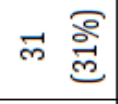 & ๓ & น & 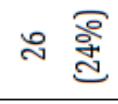 & 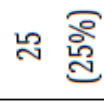 \\
\hline & 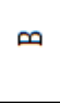 & 千高 & ヶ 哭 & దิ శ్ & ஜ & กิ స్్ㅇ & 范递 & 능 \\
\hline \multirow{2}{*}{ 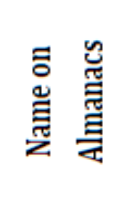 } & $\stackrel{\bigcup}{\Sigma}$ & ' & ' & 용 & 웅ㅎㅎㅇ & ₹ ঙ워 & น & ब \\
\hline & $\infty$ & . & ' & む 疛 & ১ శ్ & œ & 닝 & 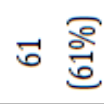 \\
\hline \multirow{2}{*}{ 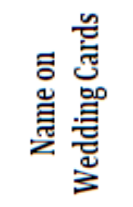 } & $\stackrel{u}{\Sigma}$ & ' & ' & ヶ 序 & ₹ ฐ্ণ & 导过 & 왕ㅎㅎ & ळ \\
\hline & 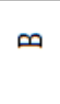 & & ' & น ํํ용 & 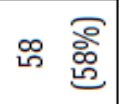 & ம & \& & 이 స్త్ర \\
\hline \multirow{2}{*}{ 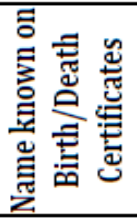 } & $\frac{v}{\Sigma}$ & 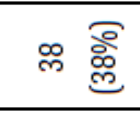 & F & ঞ & 尔离 & 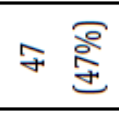 & 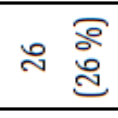 & 내 잉 \\
\hline & ఐ & ๙ ণ స్త్ర & 옹ㅎㅁ잉 & 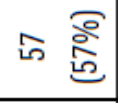 & 능 옹 & ๓ & ホな & 농 \\
\hline \multirow{2}{*}{ 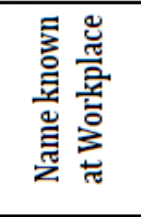 } & $\frac{U}{\Sigma}$ & ' & ' & के శ్ & $F \frac{\Xi}{\exists}$ & ঞ্ষ & 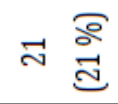 & 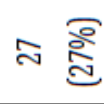 \\
\hline & 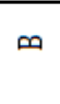 & ' & ' & 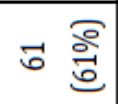 & 응 & ஸि & $\therefore \stackrel{\circ}{\Xi}$ & 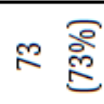 \\
\hline \multirow{2}{*}{ 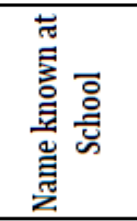 } & $\stackrel{v}{\Sigma}$ & F & 导 & 웡 & 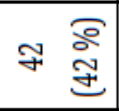 & ケ 度 & 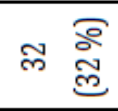 & "ా \\
\hline & 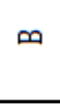 & 용ㅇㅁㅇ & ᄂ & Нั 通 & 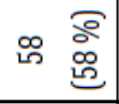 & 농 店 & 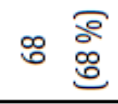 & : 。ㅇㅇㅇ \\
\hline \multirow{2}{*}{ 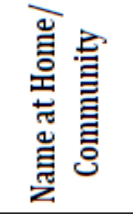 } & $\frac{u}{\Sigma}$ & $\approx$ స్త్ర & 志 & 心) & 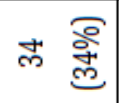 & m. & 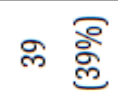 & ৫ \\
\hline & 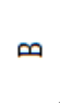 & 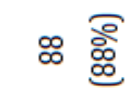 & $\therefore$ 잉 & శ శ్ శ్ర్ర & ๑ 웡 & శ శ్ర్ర & $\overrightarrow{0}$ & t) \\
\hline$z$ & & ঃ & 음 & 음 & 으 & ঃ & 우 & 。্] \\
\hline 茶 & & ำ & $\begin{array}{l}\text { ণิ } \\
\text { ஸे }\end{array}$ & $\stackrel{\text { ஸे }}{\text { जे }}$ & 早 & 누 & 官 & 辛 \\
\hline
\end{tabular}




\author{
Legend: \\ $\mathrm{N}=$ Number of respondents \\ $\mathrm{B}=$ Batonu name \\ $\mathrm{M}=$ Muslim name \\ $\mathrm{C}=$ Christian name \\ $\mathrm{M} / \mathrm{C}=$ Muslim/Christian name
}

Table 4 distinguishes the use of Batonu native names from the religious names in various domains. The domains include home/community, school, workplace, names on certificates, on wedding cards and on almanacs. It is evident from the findings that $88 \%$ (88) of the respondents made use of Batonu native names at home as against $22 \%$ (22) who used religious names. This is an indication that Batonu native names are more preferred and used at home/community than religious names. $72 \%$ (72) of the respondents claimed that Batonu native names are used during naming while $28 \%$ (28) used foreign names. Among the peer-groups, $74 \%$ (74) made use of Batonu native names as against 26\% (26) who used Muslim/Christian names. On the play ground, $75 \%$ (75) of the respondents adopted Batonu native names as against 25\% (25) that used foreign names.

There are several conclusions that can be drawn from the information in Tables 1, 2, 3 and 4. For example, in Table 1 above, there are two categories of names. The first category consists of Islamic names while the second category comprises Christian names. This means that, it is not only Muslim names that are used in Batonu, Christian names are also used. This finding is contrary to Fakuade et al (2018) who only recognize the use of Muslim names alone. Based on this finding, it can be argued that this present study has provided additional information to the previous work. Similarly, from Table 2 above, it is clearly shown that the use of Batonu native names gained dominance over foreign names (Muslim/Christian) at different levels of education. The reason for this is not farfetched. Batonu people believe so much in their culture and they hold naming in high esteem. This is why they cling to their native names.

In the religious circle (church / mosque), it is evident that most of the adherents of these foreign religions prefer to be called by the names associated with their faith, particularly when they are within their religious circles. Those foreign religions discriminate against names in Batonu. Hence, this result is in line with Fakuade et.al (2018) where they revealed the dominance of only Muslim names over the Batonu native names. However, it is not only Muslim names that are used; Christian names are also used as shown in Table 1. The dominance of Batonu native names over all other names at workplace shows that the place of work consists of so many tribes and many people want to be identified with their places of origin. On the issuance of certificates of birth and death, it was observed that Batonu native names were more frequently used than foreign names. This again indicates that the Batonu people have implicit belief in their culture. In informal domains as shown in Table 3, the use of Batonu names is more frequent. This means that the Batonu native names are culturebased.

Another conclusion that can be drawn from the data presented above is that Batonu people are more favourably disposed to the use of their native names than Christian/Muslim names which they considered as names that were not indigenous to them. The reason for their positive disposition or loyalty to the use of indigenous names is not farfetched. First, the Batonu community is largely or predominantly an agrarian society with over $90 \%$ of the inhabitants being illiterate. As a result of their occupation and their rustic lifestyle, their loyalty to their native names is never in doubt. Second, Batonu is a minority language group, therefore, users of the native names may continue to see the need for the use of the native names in order to preserve their identity as well as preserve their culture from going into extinction. Third, it is to be noted that the information in Tables 2 and 3 is in agreement with the information in Table 4 . This implies that the culture of the Batonu people inexorably impinges on their sociocultural lives as it is reflected in their preference for native names as against foreign names.

Similarly, since hegemony of Christianity and Islam in the Batonu community does not seem to have impacted positively on their 
lives, it may be said that the Batonu people display a high level of patronage to their native names. The present research work has shown that although a foreign culture may appear to have an overwhelming influence over an indigenous culture, it does not mean that the indigenous culture will not thrive especially if the indigenous culture has traditional activities that can help to sustain it. However, are there differences between the Batonu native names in Nigeria and that of the Republic of Benin? The answer to this question can be the focus of another paper.

\section{Conclusion}

We have identified different Batonu native names as well as Christian and Muslim names that are used among the Batonu people. The Batonu native names include: pre-ordained names, circumstantial/event names, lower/upper class names, chieftaincy/title names, occupational/professional names, reincarnated/ancestral names and derogatory/nicknames. We have argued that the Batonu people and some African ethnic groups share the same world-view with reference to naming in some cases. We have also examined the use of Batonu personal names and have shown how Batonu personal names are used in formal and informal domains. The research revealed that the use of Batonu native names is more predominant than the use of Christian/Muslim names in almost all domains except in the religious domain where most of the religious faithful show their adherence to Islam or Christianity. Our position is that the use of Batonu native names is more dominant than the use of Christian/Muslim names. This is in agreement with the number of respondents that claimed more frequent use of Batonu native names than the Christian/Muslim names. For example, while the use of Muslim and Christian names constituted about 26.72 percent of all the names in Batonu, the use of native names represented 73.28 percent. Therefore, this present finding is at variance with Fakuade et al. (2018) who claimed that the Batonu people favoured the use of Muslim names in both formal and informal domains.

\section{References}

Adeoye, C. L. (1972) Orúko Yorùbá. Ibadan: Oxford University Press.

Akinnaso, F. Niyi (1980) "The Sociolinguistic Basis of Yorùbá Personal Names." Anthropological Linguistics 22 (7) 275304

Andarh B. W. (1982) African Development in Cultural Perspective. Occasional Publications of Department of Archaeology and Anthropology, University of Ibadan.

Babalola, A. and O. Alaba (2003) A Dictionary of Yorùbá Personal Names. Lagos: West African Publishers Ltd

British Broadcasting Corporation (1993) London: United Kingdom http://www.bbc.co.uk/

Ekundayo, S. A. (1977) "Restrictions on Personal Names sentences in the Yorùbá Noun Phrase". African Linguistics. 19, 577.

Evans-Pritchard, E. E. (1948) The Divine Kinship of the Shillock of the Nilotic Sudan. New York: Harper and Row.

Evans - Pritchard, E. E. (1964) "Nuer Modes of Address." In Culture and Society. "A Reader in Linguistics and Anthropology (pp. 221-225).

Fakuade, G. et al. (2018) "A Shift in Batonu Personal Naming Practices." Voprosy Onomastiki. Vol. 15, Issue 1, pp. 134 - 154.

Fergusson, C. A. (1959) "Diglossia". Word. $15: 325-40$

Fishman, J. A. (1991) Reversing Language Shift. Clevedon: United Kingdom.

Gambhir S. K. (1983) "Diglossia in Dying Languages: A Case Study of Guyane Bhojpuri and Standard Hindi" Anthropological Linguistics, Vol. 25, No. 1, pp, 28-38. 
Geertz, C. (1973) The Interpretation of Cultures. New York: Basic Books.

Goke Pariola, A. (1983) " Code-mixing among Yoruba-English Bilinguals". Anthropological Linguistics. Vol. 25 Number 1:39-46.

Goodenough, H. Ward (1965) "Personal Names and Modes of Address in two Oceanic Societies." In Melford E. Spiro (ed.) Context and meaning in Cultural Anthropology. New York: Free Press. Pp. 265-76.

Ikotun R. O. (2006) "Code mixing and Linguistic Borrowing in Yoruba" Ado Journal of Languages and Linguistics. Vol. 1 Number 1, pg 66-88.

Ikotun, R. O. (2010) "The Social Use of Yoruba Personal Names." Names. Vol. 58, No. 3, pp 169-186.

Ikotun, R. O. (2013) "New Trends in Yorùbá Personal Names among Yorùbá Christians". Linguistik Online. Vol.59 (2). pp. 67-85.

Ikotun, R. O. (2014) "Surnames as Markers of Identity among the Yorùbá Sub-Ethnic Group Members". Open Journal of Modern Linguistics. Vol 4, 307 - 316.

Ikotun, R. O. and O. A. Aladesanmi (2012) "Surname Change among Some Yorùbá Christians". Journal of Emerging Trends in Educational Research and Policy Studies (JETERAPS). Vol. 3 (6) 903 - 908.

Ikotun, R. O. and F. A Soyoye (2002) "Will Multilingualism Survive in Idoani Community?" Research in African Languages and Linguistics (RALL), University of Ibadan, Vol. 6, pg 81-107

Insight on the Scripture (1988) Watch Tower Bible and Track Society of Pennsylvania, Brooklyn: New York. New York: U.S.A.

Kaye, A. S. (1972) "Remarks on Diglossia in Arabic: Well-Defined vs Ill-Defined." Linguistics, 81. 32-48.
Martins, C. B. (1959) Religious Belief. New York: Ithaca.

Ogunwale, J. A. (2003) Àwọn Wunren AjẹmóOrúko Eni àti Orúko Ibi Nínú Èdè Yorùbá. PhD. Thesis, O.A.U., Ilé-Ifẹ̀, Nigeria.

Ogunwale, J. A. (2016) Naming in Yoruba: A Sociolinguistic Exposition. Ile-Ife: Obafemi Awolowo University Press.

Oyetade, S. O. (1990) Nupe-Yoruba Endoglossic Bilingualism in Saare amd Tsaragi Community. Unpublished M. A. Thesis, University of Ibadan, Ibadan, Nigeria.

Oyetade, S. O. (1995) "A Sociolinguistic Analysis of Address Forms in Yoruba." Language in Society 24: 513-535.

Sabi, J. B. (2017). Change and Continuity among the Batombu in the Twentieth Century. An Unpublished Ph. D Thesis, Ekiti State University, Ado Ekiti.

Sanusi, I.O. (1983) "The Bariba Noun Phrase". An Unpublished B.A. Long Essay, University of Ilorin, Ilorin.

(2001) "The Syntax of Double Object Construction in Batonu. " An Unpublished PhD. Thesis, University of Ilorin, Ilorin.

Searle J. R. (1958) "Proper Names." Mind. Vol. 6. Pp.167-173

Sowande, F. and F. Ajanaku (1969) Orúko Amútòrunwá. Ibadan: Oxford University Press

Stawart, M. H. (1985) "The Borgu People of Nigeria and Benin: The Disruptive Effect of Participation on Traditional and Economic Relations. JHSN Vol. XII No. 3, P. 345.

Strawson P. E. (1959) Individuals. London: University Press.

Taylor E. B. (1892). The Origins of Culture. An Anthropological Book. London: W\&R Chamberss. 
The Holy Quran.. Text, Translation and Commentary 1983. America: Amana Corporation.

Turnbull, J. (2010) Oxford Advanced Learner's Dictionary of Current English. Oxford: University Press.

Vanderaa, I. (1991) A Survey for Christian Reformed World Missions of Missions and Churches in West Africa. Grand Rapid: Christian Reformed World Missions.

Welmers, W. (1952) "Notes on the Structure of the Bariba". Language: Vol.28, Pp.82-103.

Welmers, W. (1973) African Language Structures. Berkeley: University of California Press. 